planning. Along these lines it should be possible in due course not only to ascertain the value of our possessions but also to get some idea of the potential capacity of our people, and thereby to raise the general standard of living and national culture to a much higher level than we have yet achieved.

\section{ETHICAL AND POLITICAL REMODELLING OF SOCIETY}

\section{By SIR FREDERIC KENYON, G.B.E., K.C.B., F.B.A.}

7 HE rehabilitation of a wrecked and bewildered world will be the task of the years which lie immediately before us. In 1919 we hoped that we might restore the world as it was before 1914, with additional provision for its security. In 1942 we know that that attempt failed, and that when the present threat to civilization has been defeated it will be necessary not to restore an old world but to lay the foundations of a new one. A movement which has been in progress for a generation has been greatly accelerated. The foundations of society have been broken up. A new outlook on social relations has become necessary, and we have to orient ourselves in the new circumstances.

Up to the outbreak of the War of 1914-18 we were in effect living on the Liberal philosophy and political economy of the middle of the nineteenth century. Its corner-stones were individualism, laisser-faire and free trade; its prophets were Mill, Herbert Spэncer, Fawcett. The State should interfere as little as possible. The individual should be left to develop in his own way; to buy in the cheapest market and sell in the dearest; to aim at material welfare and let the devil take the hindmost. It was a philosophy unimpeachable if once you accepted its fundamental axiom, that the whole duty of man is to cultivate material prospэrity. Its best exponents recognized that the 'economic man', for whose conduct they enunciated principles, was not necessarily the whole man; but the politicians and the popularizers of scientific thought ignored this qualification, and for some three generations these doctrines governed the thought and the political practice of the nation.

There were always some-Carlyle, Ruskin and the Christian Socialists notably — who combated a political economy which they accused of being soulless. There were always some who maintained that, while unrestrained individualism was good for the strong and might bring wealth to a State, it involved unjustifiable suffering for the weak. A sense of social responsibility began to grow, and took visible form in the 'eighties, in such movements as the Salvation Army and the foundation of university settlements. Gradually, almost unconsciously, the State and the local administrations accepted more and more responsibility for the welfare of the people. The 'social services' assumed an ever-increasing importance in national and local budgets, which meant in fact that the larger incomss ware curtailed for the benefit of the smaller. The War of 1914-18 intensified this movement; it gathered strength in the uneasy years of peace from 1918 until 1939; and with the now War it has come with a rush. The State has assumed control of nearly every form of activity. Large incomss are taxed to the verge of extinction. Hundreds of millions are drawn from the profits of individuals and companies and applied to keeping down prices for the poorer classes and increasing their earnings. The exigencies of war have brought us to accept, almost overnight and without a atruggle, an almost complete measure of national socialism, and a very extensive levelling up and down of incomes. The problem now before us is, how much of this remodelling of society should and could be carried forward into the years of peace which will follow when once the forces of evil, with which we are engaged in a death-struggle, have been overcome.

The great danger is lest this problem should be approached under the old forms of political controversy, with the leaders of each party striving to stake out claims for those whom they represent, and to turn to their material advantage the opportunities of the moment. This, by whatever party it is practised - employer or employed, capital or labour, the 'haves' or the 'have-nots'-is war profiteering, the turning of the exigencies of war to one's own material profit. It may be more justifiable on one side than on the other; but the basis is the same, the nineteenthcentury doctrine that everyone should do the best he can for his own material advantage.

The remedy needed is something far more fundamental. We have been so saturated with the doctrine that material welfare is the prime aim of life that we do not realize that it has not always been so. Material welfare has, no doubt, always been a motive of human action, and often a powerful one, but it has by no means always been the predominant one. It has not always been held that man lives for bread alone, or that "they should take who have the power, and they should keep who can". We know now to what the unrestricted application of this doctrine has led us. We want now to reconsider its validity, objectively and impartially, and to determine how it can be improved or replaced.

We want, in fact, a new political philosophy ; and in this phrase the epithet is not used in the restricted sense of parliamentary and municipal controversies, "where ignorant armies clash by night", but in the sense in which "politics" means the art of living together in a civilized and organized community. This art has to be thought out afresh, and the thought needs to be as unimpassioned as possible. It is also of the first importance that the thinking and the formulating of its results should be done without delay, in order that the field may not be pre-occupied by the combatant politicians (in the narrower sense), and that the results of dispassionate thought may be at the service of the statesmen who eventually have to lead the reconstruction of our national life.

It is for this reason that the establishment of some form of central organization of sociology seems to many persons to be a desideratum. Just as the Institute of International Affairs serves a useful purpose in the collection of facts and the formation of opinion on international matters, and as institutes of archæology or chemistry or chartered accountancy bring together those who are interested in these subjects for the interchange of views, so a similar organization for sociology would serve as a forum for the formation of the new philosophy of social relations which seems to be needed. This is not so unpractical a proposal as it may seem to those who are satisfied with the limited vision of immediate controversy. It does not mean that long-bearded and unpractical scholars will sit down to elaborate papər constitutions or new Utopias. It means rather that those who are engaged in social activities will pool their experiences, will be invited to formulate 
their principles, and will be encouraged to work on a basis of co-operation rather than controversy, to see how much harmony can be achieved, not how much can be seized by force from an unwilling opponent.

For the operations of such an organization some guidance can be derived (as in so many other provinces of thought and science) from the Greeks. For Plato and Aristotle and their followers ethics and politics were intimately connected. The virtues of the State were the virtues of the individual, writ large. The social and political ideal of Aristotle is thus expressed by Mr. W. L. Newman :

"The State exists for the exercise of the qualities which make men good husbands, fathers and heads of households, good soldiers and citizens, good men of science and philosophers. When the State by its education and laws written and unwritten succeeds in evoking and maintaining in vigorous activity a life rich in noble aims and deeds, then and not till then has it fully attained the end for which it exists. The ideal State is that which adds to adequate material advantages the noblest gifts of intellect and character, and the will to live for their exercise in every relation of life, and whose education, institutions and law are auch as to develop these gifts and call them into full play."

It is indeed the restoration of the connexion between ethics and politics that must be the principal aim of the new social philosophy. The whole tendency of political thought in the nineteenth century was to divorce them. Religion was excluded from the education given by the State, because religious dissensions divided the people so deeply. The current political economy deliberately excluded moral considerations, in order to concentrate on purely material considerations. In every department of life, in art and literature no less than in economics and politics, the intrusion of morality or religion was resisted. The economic man, not the ethical man, was made the basis of political theory, and material wealth was the goal of political practice.

The last hundred years have seen these principles tried out, and we are now in a position to estimate the result-a considerable amount of material success, leading to a moral debacle. It would be the task of the organization proposed to study how the good can bes separated from the bad; how freedom of the individual in thought and action can be made compatible with justice to all ; how individual initiative can be encouraged without exploitation of the less fortunate masses; how the standard of life can be raised for the many without forfeiting the benefit which the whole community receives from the excep. tional abilities of the few. We have been told that oivilization has become mechanized; what it needs is to become moralized. We have before us terrible examples of the results of totalitarian control unrestrained by morality. We can see its efficiency, and we can also see its demoralizing effects. The new political philosophy must aim at securing the first without incurring the second; and this can only be achieved by the objective and dispassionate thought which an organization for sociology would cultivate.

We cannot afford to wait for an individual to give us the guidance which we need. If such a genius should appear, to be the Adam Smith or the John Stuart Mill of a new generation, it would be a godsend; but the need is urgent, and the ground can at least be prepared by co-operative effort. From such effort we may hope to obtain that philosophy of human affairs which Socrates, twenty-three centuries ago, declared to be necessary for the right conduct of life.

\section{RESEARCH IN THE HISTORY OF SOCIOLOGY \\ BY ALEXANDER FARQUHARSON \\ General Secretary, Institute of Sociology}

T $N$ any discussion upon the better organization of research in the social sciences in Great Britain the question of the place to be assigned to historical research will inevitably arise. This article leaves on one side the problems of the general development of research in social, economic and cultural history, and considers only the need for research in the history of the scientific study of society. The intimate connexion between that history and the general history of thought and of science will not be forgotten.

The history of the scientific study of society may be conceived in a wider or narrower sense. At its widest it may be taken as including all attempts throughout the history of mankind to present a systematic and consistent picture of the structure and development of particular societies and of group. ings of such societies up to the limits of the known world. The work of Herodotus in the Hellenic world, of Ibn Khaldun in the Moslem world, and of Lord Hailey and his colleagues in the recent "Africa Survey"- to take three handy examples onlywould fall under this definition. Research might deal with such topies as methods used (personal observation, second- or third-hand report, forms of record), models followed, the debt of each worker to what went before, a comparative study of interpretations of phenomena recorded.

A great part, however, of the work to be done would be in a field already occupied by historians as students of methods used and interpretations adopted in historical studies. An account of a society at a particular moment of time in the past has in general already won recognition as a source for its history, and in many cases has been subjected to an intensive critical examination ${ }^{1}$. Further, there already exist general critical accounts of such sources for particular epochs and territories, and also general accounts of the development of historical studies, the accumulation of material for these, and the growth of historical method.

The impossibility of separating the 'static' and 'dynamic' views of society becomes even clearer when pre-history and archæology are considered. The same material remains must be used in reconstructing either a picture of social conditions at a moment in the past or a panorama of social development from stage to stage. Further, this wider history must take account of theories of society, from Aristotle to Toynbee, and the critical work already expended on these by historians, philosophers and sociologists.

The historian of the scientific study of society must accept all this accomplished work as the foundation of his own. He has, however, something fresh to contribute, and that something is of extraordinary value. One aspect of it is the attempt to relate the historical outlook and methods of each epoch and its theories of society to the political and social structure and the culture of that epoch. The other aspect is the attempt to assist the re-shaping of historical studies to harmonize with the political and social structure and culture of the present and the immediate future. In Great Britain the latter task is already in hand ; for historical studies in recent years have been notable for their reflection of current interest in social and economic problems; to-day the weight assigned 